\title{
Teachers' and Students' Perceptions on Blended Learning in Tertiary English Language Courses: A Match?
}

\author{
Angkana Tongpoon-Patanasorn ${ }^{1, *}$, Cynthia White ${ }^{2}$ \\ ${ }^{1}$ Faculty of Humanities and Social Sciences, Khon Kean University, Thailand \\ ${ }^{2}$ College of Humanities and Social Sciences, Massey University, New Zealand
}

Received March 11, 2020; Revised April 11, 2020; Accepted April 27, 2020

Copyright $\mathbb{C} 2020$ by authors, all rights reserved. The authors agree that this article will remain open access under the terms of the Creative Commons Attribution License 4.0 International License.

\begin{abstract}
Although blended learning has long been recognized in the field of English language teaching, it is often claimed that it has not reached its optimal level of effectiveness in this area. This study aims to examine teachers' and students' perceptions of the design of blended learning in English language courses. The study participants consisted of five English teachers, each of whom had over a year of experience in teaching blended learning courses, and thirty-six students majoring in English. The data were collected using semi-structured interviews with teacher participants and focus group interviews with student participants. The interviews were conducted using both face-to-face and phone conversations; each interview lasted about one hour. The focus group interviews were conducted with four to five student participants at a time, and each interview lasted about one hour. Conversations with both the teacher and student participants were conducted in their first language to allow for greater insight. The data from the interviews were transcribed and coded using Atlast.ti, and they were then analyzed using content analysis. To validate the results, the emergent themes were reviewed by the participants. The results revealed that both teachers and students were ready for this new form of language teaching. What is needed is teachers' professional training on how to design blended learning courses beyond the course management system level and how to raise and maintain students' motivation for online learning. Unsurprisingly, teachers are viewed as the main agents in enabling successful English language learning.
\end{abstract}

Keywords Blended Learning, Teachers' Perception, Students' Perception

\section{Introduction}

Due to technological disruptions, higher education professionals have been required and encouraged to provide a learning environment that better meets the new way students are learning and to demonstrate the effectiveness of such a program. The new teaching and learning paradigm and environment must be able to engage learners to enhance students' abilities to attain higher levels of learning and thinking [1-3]. The current suggested practice within higher education is blended, or hybrid, learning [4]. Blended learning, which is one form of flipped classroom, is also referred as the "new normal model" [5, p.167], the "new normal" [6, p.207], or the "new normal with emerging technologies" $[7, p .1]$ in the delivery of higher education courses. It is believed to be the future of education [9].

Blended learning is a form of personalized learning, which involves the integration of online learning and faceto-face instruction [10] with "reduced in-class seat time for students" [11, p.1]. Previous studies [8,12-21] have examined the role of blended learning in a wide range of contexts, from K-12 to tertiary-level education. They have similarly reported that blended learning was effective in enhancing students' access to successful learning and that students had positive perceptions of learning through blended learning. Blended learning provides constructive learning experiences and contains elements that may not be found in traditional, or face-to-face, instruction, and that can foster higher levels of learning [22].

Despite positive evidence concerning the effectiveness of blended learning, some scholars state that it has not yet reached its full potential in enhancing learners' achievement and learning experiences [23, 24]. This failure can be attributed to teachers' resistance [25] and inadequate professional training [26]. 
In the context of Thailand, blended learning has been widely used in higher education. However, most studies have been conducted to develop blended learning courses and examine its effectiveness. For example, Sriprasertpapap [27] developed an online learning model for students, teachers, and employees. Five elements vital for the development of blended learning courses included creativity, Learning Management System (LMS), instruction media, interaction, and evaluations. Tananuraksakul [28] found that blended learning could motivate learners to learn English and enhance positive attitudes towards learning English as a foreign language. However, a study by Thomas[29] found that there was an association between blended learning and learners' academic outcomes, even though it was rather weak.

To the best of our knowledge, only one study, which was conducted by Woods, Baker, and Hopper[30] has examined teachers' practices in a blended environment. In Thailand, Simasathianaophon [31] examined teachers' and students' perspectives on the benefits and challenges of blended learning. However, he did not specifically examine teachers' and students' perspectives on English language learning Moreover, previous studies have rarely examined the actual practices used by teachers in blended learning; instead, they seem to focus on teachers' perceptions of specially designed courses. Teachers are the main agent who provides learning experiences that ensure learners' academic achievements. In addition, understanding students' perceptions on the role of blended learning in the development of English skills will provide better insight into how blended learning is viewed by the user. Greater insight into how teachers design and develop blended learning in English classrooms and how blended learning should be delivered will provide better understanding and methods to enhance the effectiveness of blended learning in English language teaching. Therefore, the main research questions for this study are as follows:

1. How do English language teachers design and develop blended learning?

2. What are teachers' and students' attitudes toward blended learning in English classes?

\section{Blended Learning}

Blended learning is a combination of two modes of teaching: distance learning and face-to-face instruction [32]. Blended learning provides learners with the opportunity for personalized learning, allowing them to learn at their own pace in a chosen place and at a chosen time. It is well documented that blended learning leads to more positive learning experiences and higher learning outcomes [33,34]. It can also enhance teaching pedagogies and student engagement $[35,36]$. Teachers play important roles in the success of blended learning [37] due to the fact that they are the main practitioners designing, developing, and implementing blended learning courses.

\section{Materials and Methods}

This study adopted a qualitative approach to understand how teachers design and develop blended learning approaches in English courses, how teachers and students perceive the effectiveness of blended learning, how teachers actually implement blended learning in English classes, and how students view the role of blended learning.

\subsection{Participants}

The participants consisted of five English language teachers (three males and two females) who were selected purposively because they each had at least one year of experience in using blended learning in English language courses, and 36 second-year English majors (six males and 30 females) enrolled in one university located in the northeast region Thailand. Teachers and students were asked to volunteer for the study personally. Only those who agreed to participate were contacted for interviews.

\subsection{Materials}

Semi-structured interviews with teachers were designed to elicit how the blended learning approach was used in their teaching practices, how they integrated technology or online learning into learning and teaching, what technology they used in their classes, how feedback was given to students, and what challenges they had faced. Focus group interviews with students were used to examine their experiences of blended learning, what challenges they faced in blended learning classes, and how blended learning should be designed and delivered for optimal learning outcomes. During the interview, the term "blended learning" was used minimally since some teachers and all students were not familiar with the term. The words "technology," "online learning," or "eLearning" which were more familiar to the teacher and student participants were used when referring to blended learning. The following are the interview questions for the teacher and student participants.

\section{Interview questions for teachers}

Aim: To elicit perceptions and current practices on blended learning in English language teaching (ELT).

1. Do you use technology/online learning/e-Learning in your English language teaching? If yes, in what course(s)? How do you design your courses to integrate technology/online learning/e-Learning in English language teaching?

2. How do you think technology/online learning/ eLearning benefit students' English language learning? 
3. How should technology/ online learning/ e-Learning be integrated into English language teaching?

4. What types of language activities should be put/not put online?

5. How do you provide input/ opportunity for language production/ feedback to students in online learning?

6. What challenges did you face when integrating technology/ online learning into your courses?

\section{Focus group interview questions for students}

Aim: To elicit students' opinions on the use of blended learning in ELT.

1. Have you taken English language courses that integrated online learning/e-Learning? What were they? What learning and language activities were you required doing in those courses? What do you think about the courses? Explain your experience learning in such courses.

2. What do you think about the use of technology/online learning/ e-learning in English classes?

3. How do you think technology/online learning/eLearning should be used in ELT to best improve your English?

4. What types of language activities should be put/not put online?

5. How do you think input/opportunity for language production/ feedback should be delivered to students?

\subsection{Data Collection}

Potential teacher participants were contacted individually, and only those who agreed to participate in the study were interviewed. The interviews were conducted using both face-to-face and phone conversations; each interview lasted about one hour. The focus group interviews were conducted with four to five student participants at a time, and each interview lasted about one hour. Conversations with both the teacher and student participants were conducted in their first language to allow better insight into issues and recorded with the participants' permission. Careful notes were also taken during the interviews. Since the term "blended learning" might not have been understood well by both teachers and students, different terms that were more familiar to the participants, such as "e-learning," "using technology in classroom learning and teaching," and "online learning" were used to refer to blended learning.

\subsection{Data Analysis}

The data from the interviews were analyzed using content analysis. The interviews were transcribed and coded using Atlast.ti. Similar ideas were grouped together and categorized, and a theme/title was given to each category. The participants were asked to review these themes that emerged to validate the findings [38].

\section{Results}

\subsection{Teachers' Actual Blended Learning Practices and Students' Experiences with Blended Learning in English Language Learning}

The five teacher participants reported that they employed blended learning in different English courses, which included classes on pronunciation, note-taking, reading, and speaking. In the pronunciation class, blended learning was integrated by requiring students to participate in pronunciation activities online, including checking the pronunciation of words and sentences via assistive tools, for example, Apple's Siri, recording their pronunciations and submitting them online. In the reading class, students were required to download online reading materials and prepare for in-class discussions via Google Classroom. In the speaking class, students were asked to participate in paired speaking activities and upload their video clips to Google Classroom. In the note-taking class, all class materials were uploaded to Google Classroom since the teacher aimed to achieve a paperless class. Activities conducted via blended learning included checking class attendance, making class announcements, providing links to video clips that students needed to take notes on, vocabulary logs (i.e., after watching a clip, students selected ten unknown words for their vocabulary logs). All five teachers used Google Classroom for online learning, and they all reported having received no training on blended learning. Their integration of blended learning was based on individual interests and views on how to make learning more successful and manageable.

Students reported positive experiences with regards to learning online. The students mentioned that learning online, e.g., through Google Classroom, made learning more accessible: they could access class materials at any time; they did not need to go to school to learn; they were able to study, download class materials, and hand in their assignments from coffee shops, dormitories, and even rice fields. Google Classroom stored their assignments and homework, thus they could keep track of their work, making them confident that none of their work had been lost. Through online learning, they were able to review class materials more conveniently, including handouts, PowerPoint presentations and video clips of previous lessons. Moreover, it was quite convenient for them to send private messages to their teachers when they had questions.

Student No. 2: I like studying online because I can download the material and study it anytime. I know that it is there. I will not lose my assignments, and I know that the teacher will not lose them either.

Student No. 11: Online learning gives me freedom. I 
can choose when I want to study or when I want to stop. When working on my assignment, I can take my time to think carefully, and, when I am lazy, I just stop and continue my work when I am ready.

Student No. 29: I can go back and review the materials anytime, and, when I have questions, I can send a message to ask the teacher.

\subsection{Teachers' and Students' Views on Learning Behaviors and Styles and Blended Learning}

When asked about students' learning behavior and technology, it appears that the teacher participants believed that learning online would help increase students' learning autonomy, which is part of the required skillset for the 21 st century. The teacher participants felt that technology seemed to fit well with students' learning behaviors and styles.

Teacher No. 1: Online learning and technology are appropriate for students' learning because mobile phones are part of their lives. They are addicted to using mobile phones. When using online learning, students are more motivated, actually, are forced, to learn because they are required to use mobile phones to do class activities, and class materials appear on their mobile phone screens, so they have to pay attention to them. The good thing is that they cannot use their mobile phones to do other things while working on class activities.

Teacher No. 2: Blended learning is appropriate for modern language teaching and students in this disruptive technology era. It is the right direction to go in.

Teacher No. 4: Online learning fits students' interests and learning behavior. Students are now more active learners, and their motivation is high when learning online.

As mentioned earlier, students reported that learning, downloading materials, and submitting assignments online were convenient because they could access the materials and submit assignments from anywhere at any time. However, all students reported that they still wanted to meet face-to-face with teachers in class.

Student No. 19: Technology provides students with easy access to the course materials and submission of assignments. However, I still prefer meeting with the teacher in class because I feel I understand the materials more. When in class, the teacher can explain things and clarify difficult points for me.

Student No. 35: I think students our age are quite familiar with using technology for learning, but I think we still prefer being in the classroom, meeting with the teacher and classmates, because I like it when the teacher adds more techniques or new knowledge in class, such as about grammatical points or even personal life experiences that could not be found in the online lesson. That makes me learn more.

Interestingly, one student (Student No. 4) mentioned that "students today are different from students in the past. We have short concentration spans. It is easy for us to get distracted and go on other websites or applications, like social media. So, the lesson should be well designed, guidance should be provided at the beginning of the lesson, and a summary of major points (e.g., mind map or handouts) should also be provided."

\subsection{How Blended Learning Classes Were and Should Be Designed for Teaching English Effectively}

For the design of blended learning, it was mainly integrated in English courses as a course management tool for teachers and students to upload and access course materials, to give and submit assignments, and to give and receive feedback. Main learning activities were conducted through face-to-face classroom instruction. The participating teachers felt that advanced technology and more rapid and stable internet service have made blended learning more successful. It was particularly helpful for classroom management, making it more convenient for teachers and students to post and access course materials online, assign and submit assignments, and give and receive feedback. Blended learning tools, such as Google Classroom, can store assignments and feedback, allowing students to revisit the material many times throughout the semester.

The teacher participants also mentioned that to teach English successfully, it is vital to incorporate English language learning theories into the design of blended learning courses. Blended learning should be designed to provide input (i.e., language samples) in the form of classroom materials, such as reading material, video clips, texts with audio, interactions with native speakers, and so forth, thus providing the opportunity to learn both explicitly and implicitly as well as for learners to have more practice and produce more output (language production). Since most teachers saw blended learning as a course management system, it seemed to be very challenging to design blended learning courses that would enhance learners' English abilities. The last vital element for the design of blended learning was the provision of guidelines for learners on how to effectively participate in online activities. (Table 1) 
Table 1. Goals in the design of blended English learning classes

\begin{tabular}{|l|l|}
\hline Teacher & Student \\
\hline$\bullet \quad \begin{array}{l}\text { Course management system } \\
\text { Incorporation of English language learning theories: } \\
\text { input, learn implicitly and explicitly, practice, and } \\
\text { language output (production) } \\
\begin{array}{l}\text { Provision of effective guidelines } \\
\bullet\end{array}\end{array}$ & $\begin{array}{l}\text { Provision of clear guidelines } \\
\text { Provision of various language activities related or not related to the } \\
\text { coursective }\end{array}$ \\
$\begin{array}{l}\text { Appropriate length of texts } \\
\text { Use of other media to create a better learning environment }\end{array}$ \\
\hline
\end{tabular}

Teacher No. 2: Technology can provide more content to students. It makes content more accessible for students. For successful language learning, I think language classrooms in a blended learning form should still provide the same learning ingredients that traditional classrooms can provide, such as actual language production with the teacher and peers. Blended learning is just the change of a learning mode from actual classroom to virtual classroom.

Teach No. 5: I think even though students are quite familiar with online learning, they must be given guidelines to help them take part in online learning activities successfully, or they will easily get lost.

Based on their experiences with blended learning, the students felt that their English could be enhanced via the provision of more and various language activities related to classroom objectives and materials, such as language games, online vocabulary activities, opportunities to interact and speak with native speakers and peers, and interactive reading activities. Video clips should be held to an appropriate length, i.e., they should be relatively short so that students can maintain their concentration. Other activities, such as steaming or live chats through such applications as Zoom or Google Hangouts Meet, would make learning more interesting and successful in terms of practicing the language. Also, it would be very beneficial for learners if classroom lectures could be filmed and uploaded online. Interestingly, the student participants also mentioned that language activities, such as vocabulary games, grammar exercises, and English learning techniques that may or may not related to course objectives or materials, and language tools, such as online dictionaries, grammar checkers, and paraphrasing services, should be provided. Clear guidelines and guidance should be provided to learners for successful learning. Surprisingly, all students reported that they were not ready for full online English courses. They still needed assistance from teachers in reviewing and wrapping up main points in order to obtain a higher level of understanding and more classroom practice to enhance their language abilities. A ratio of approximately $30-40$ online activities to face-to-face classroom meetings would make learning English effective for them.

Student No. 1: I think online learning is good because I can manage my own learning, but I still want to be in class meetings with the teacher. In class, I can learn different English language learning techniques from the teacher, and, most importantly, I liked to learn about the personal experiences the teacher shared in class.

\subsection{Perceptions of Teachers' Feedback}

All teachers reported giving feedback online via the feedback function provided by Google Classroom. Feedback took the form of both scores and comments. All teachers mentioned that Google Classroom provided teachers with time flexibility when providing feedback. They were allowed more time to mark and give comments on students' work, and they could provide better feedback and comments. In class, time constraints did not allow them to provide detailed feedback to students. One teacher mentioned that he/she gave two different forms of feedback. When students submitted their work, the teacher would first provide short, spontaneous responses to the submissions, such as good, very good, and thank you, and then later provide scores or more extensive comments on the same work. However, one teacher mentioned that feedback was also dependent upon the nature of the task. For some tasks, such as writing, face-to-face feedback may be more effective because the teacher can then provide more complex explanations and offer students the opportunity to ask further questions and discuss unclear points.

The student participants reported receiving both forms of feedback (i.e., scores and comments). All students were satisfied with online feedback because they could repeatedly visit Google Classroom to review comments and feedback at their own convenience. However, they still believed that it was more useful when the teacher provided comments and feedback in the physical classroom. Interestingly, a few students mentioned that they preferred online comments and feedback to face-toface comments because it allowed them sufficient time to react to negative comments appropriately. In one student participant's own words, "I prefer online feedback and comments because sometimes in class when the teacher gave comments, I was shocked and felt embarrassed. I had been working on the assignments and projects for many days and weeks, so even minor negative points could break my heart. So, I prefer online feedback because I could secretly study the comments, and they were always there. I could review them anytime when I was ready" (Student No. 19). 


\subsection{Teachers' and Students' Challenges}

The main challenges faced by the teacher participants were a lack of understanding of how to design blended learning properly to provide appropriate positive learning experiences leading to greater language skills and how to assess students appropriately in terms of English and technology skills (the acquisition of technology skills was a course objective). Additionally, it seemed that the teachers still lacked the technology skills necessary to deliver online learning activities successfully. Technicians and consultants are needed for teachers to conduct online learning successfully. Another challenge concerned the greater workloads required for integrating technology into language classrooms, i.e., teachers had to work harder in terms of designing online courses, developing materials, and providing feedback and comments. Finally, since learners were able to learn at any time, it was challenging for teachers to educate students about the etiquette involved in sending enquiries or calling teachers, particularly in terms of appropriate hours for such contact. All the teachers agreed that this was a major challenge to manage. On one hand, ignoring students' messages or calls may lower their motivation to learn. On the other hand, teachers need to protect their privacy. (Table 2)

Teacher No. 2: To successfully improve one's language ability, one must be exposed to a large amount of input, able to learn both explicitly and implicitly, and, importantly, have opportunities to produce the language or interact with other students or native speakers. It is challenging to design blended learning to create an appropriate environment for English development to occur.

Teacher No. 5: Teachers are required to work harder and to give better and more elaborate feedback on students' work in a timely manner.

Teacher No. 3: Students often called me or sent me messages at night or very late at night to ask for help with how to do activities, what to do next, and sometimes just wanted to know how I was doing. It was hard to refuse or ignore them.

Regarding students' perceptions, the first important challenge students encountered in a blended learning classroom was motivation. The student participants mentioned that it took a high level of discipline, and was very challenging, to motivate themselves to complete activities online. When asked how they were persuaded to learn online, they mentioned receiving credit for online activities. Techniques such as selecting "Best Online Student of the Week," earning small gifts from teachers due to good marks, and receiving certificates for completing requirements may motivate students to learn more. Moreover, activities should be well designed and practical so that they can be applied in real life outside of the classroom. Another challenge was internet connections. Students need to have high-quality internet connections to participate in blended learning, and such connections may not be available everywhere.
Student No. 38: It was just hard to get online to do activities. I sometimes delayed until it had to be done, but I know I have to do it.

Student No. 9: Probably, we know that it is there. We can go there anytime we want, so we can wait until we really feel we need to do it.

Table 2. Challenges of blended learning

\begin{tabular}{|c|c|}
\hline Teacher & Student \\
\hline $\begin{array}{ll}\text { - Insufficient training on blended } \\
\text { learning principles (e.g., course } \\
\text { design and student evaluation) } \\
\text { - } \quad \text { Insufficient technology skills } \\
\text { - } \quad \text { Higher level of workload } \\
\text { - Blended learning etiquettes }\end{array}$ & $\begin{array}{ll}\text { - } & \text { Motivation } \\
\text { - } & \text { Internet } \\
& \text { connection }\end{array}$ \\
\hline
\end{tabular}

\section{Discussion}

The findings showed that teacher participants mainly used Google Classroom in their blended learning classrooms. However, they used it largely as a course management system. When blended learning was implemented in classrooms, it was more often used as a tool to help a teacher deliver course materials, assign homework, and make announcements, and to assist students with submitting and storing their homework. Even though this practice may enable students to increase self-regulation and learner autonomy levels [39], it seems that blended learning has not been able to achieve its optimal application in English language learning. This failure may be due to the fact that all the teachers interviewed in this study, and probably numerous teachers around the world, lack professional training on blended learning and the integration of English language learning and teaching theories with blended learning [26]. Teachers realize the important role of technology and blended learning in language learning and teaching, but require training that would help them to adopt blended learning in English language teaching and assessment more successfully.

None of the resistance on the part of teachers and students reported in previous studies [25, 40-43] was found in this study. It seems teachers and students were ready for this new platform for learning. Teachers seemed to believe that students were ready to take responsibility for their learning. It appeared, however, that students, even though they perceived the usefulness of online learning and being able to manage to work both online and face-to-face in classrooms, needed clear and detailed guidance from teachers to work successfully in a blended learning environment [44]. It cannot be assumed that students are ready to work autonomously. Guidance is vital for language learning to occur [45]. Guidance may also help reduce inappropriate contact from students late at night. Along the same vein, training on blended 
learning etiquette is needed, as etiquette is one of the prominent generic items which should be factored into the design of a successful blended course [44]. According to François [44], etiquette concerning ethical behavior in terms of online interactions, confidentiality, and privacy must be addressed, and a "netiquette" agreement must be planned and designed to ensure appropriate conduct on the part of students.

Finally, motivation was found to be the most crucial factor in blended courses. Even though they favored blended courses, it appeared that motivating themselves to study online was very challenging for students. It is important to note that the finding of this study did not support previous literature on motivation, suggesting that students are more engaged and motivated in blended learning [1-3,22,28]. Also, it seemed there was a mismatch between teachers' beliefs (i.e., students were familiar with technology and motivated to learn online) and students' beliefs (i.e., students lacked self-discipline and motivation to learn online). This issue should be taken into consideration when conducting future blended learning studies and designing blended learning courses. According to François [44], teaching effectiveness involves the appropriate design, planning, and delivery of a blended course. These elements will help maintain students' motivation and ensure student satisfaction. To design a successful blended course and maintain students' motivation, the course should be designed with four major characteristics in mind, namely attention, relevance, confidence, and satisfaction (ARCS) [46]. The course should be able to arouse and maintain students' interest and curiosity, or attention. Learners must perceive the importance of learning and how it has value in their personal lives. Learners must also believe that they are able to achieve learning goals or increase their confidence. Finally, learners' satisfaction must be reinforced.

\section{Conclusions}

The main aims of this study were to examine teachers' and students' perceptions of the design of blended learning and understand their views on how to achieve successful blended English language courses. The results showed that there was no resistance on the part of teachers or students. Teachers and students were ready for this new form of learning in English language classes. What is lacking at this point is teacher training in designing successful blended courses for language learning, going beyond the use of blended learning as a course management system, and sufficient student preparation to engage successfully in blended learning. Motivation is still a major concern for both teachers and students. However, with more advanced technology, such as AI (artificial intelligence), and better knowledge of blended learning design in English language teaching, teachers will be able to design positive blended learning experiences for students, who, in turn, will be able to successfully improve their English language abilities. Future studies should include students in the blended learning development process to better fit students' needs and views on how they would learn best. This was an exploratory study with a small number of participants. Future studies should include more participants to confirm its findings. Also, students from diverse language backgrounds may have different learning styles and behaviors. As a result, learners with different cultural backgrounds should be included in future work.

\section{Acknowledgments}

We would like to thank Khon Kaen University for funding this research project. Without its financial support, it would not have been possible to complete this project. Also, we would like to thank all participants for their participation in this study, and blind reviewers for their valuable comments and feedback during the preparation of this manuscript.

\section{REFERENCES}

[1] E. F. Barkley. Student engagement techniques: A handbook for college faculty, Jossey-Bass, San Francisco, CA, 2010.

[2] C. Bryson, L. Hand. The role of engagement in inspiring teaching and learning, Innovations in Education and Teaching International, Vol.44, No.4, 349-362.

[3] H. Coates. Student engagement in campus-based and online education: University connections, Routledge, London, 2006.

[4] R. Cobcroft, S. Towers, J. Smith, A. Bruns. Mobile learning in review: Opportunities and challenges for learners, teachers, and institutions, Proceedings of Online Learning and Teaching, (OLT) Conference, 21-30, 2006.

[5] B. Ross, K. Gage. Global perspectives on blended learning: Insight from WebCT and our customers in higher education, in C. J. Bonk, C. R. Graham (Eds.), Handbook of blended learning: Global perspectives, local designs, 155-168, Pfeiffer, San Francisco, CA, 2005.

[6] A. Norberg, C. D. Dziuban, P. D. Moskal. A time-based blended learning model, On the Horizon, Vol.19, No.3, 207-216.

[7] C. Dziuban, C. R. Graham, P. D. Moskal, A. Norberg, N. Sicilia. Blended learning: The new normal and emerging technologies, International Journal of Educational Technology in Higher Education, Vol.15, No.3, 301316 . Available online from https://doi.org/10.1186/s41239-017-0087-5

[8] C. Dziuban, A. G. Picciano, C. R. Graham, P. D. Moskal. Conducting research in online and blended learning 
environments: New pedagogical frontiers, Routledge, Taylor \& Francis Group, New York, 2016.

[9] M. Brown, V. Diaz. Blended learning: A report on the ELI focus session, 2010. Available online from http://net.educause.edu/ir/library/pdf/ELI3023.pdf

[10] C. R. Graham. Emerging practice and research in blended learning, in M. G. Moore (Ed.), Handbook of distance education, 3rd ed., 333-350, Routledge, New York, 2013.

[11] L. Lewis, B. Parsad. Distance education at degree-granting postsecondary institutions: 2006-07 (NCES 2009-044), Washington, DC. Available online from http://nces.ed.gov/pubs2009/2009044.pdf

[12] C. J. Bonk, C. R. Graham. The handbook of blended learning: Global perspectives, San Francisco, CA: Pfeiffer Publishing 2006.

[13] M. C. Bueno-Alastuey, M. V. L. Pérez. Evaluation of a blended learning language course: Students' perceptions of appropriateness for the development of skills and language areas, Computer Assisted Language Learning, Vol.27, No.6, 509-527.

[14] D. R. Garrison, N. D. Vaughan. Blended learning in higher education, Jossey-Bass, San Francisco, CA, 2013.

[15] E. Jean-François. Transcultural blended learning and teaching in postsecondary education, Information Science Reference, Hershey, PA: Information Science Reference, 2013.

[16] A. Kitchenham. Blended learning across disciplines: Models for implementation, information science reference, Hershey, PA, Hershey: IGI Global, .2011.

[17] B. Means, Y. Toyama, R. Murphy, M. Baki. The effectiveness of online and blended learning: A metaanalysis of the empirical literature, Teachers College Record, Vol.115, No.3, 1-47.

[18] A. G. Picciano, C. D. Dziuban. Blended learning: Research perspectives, The Sloan Consortium, Needham, 2007.

[19] A. G. Picciano, C. Dziuban, C. R. Graham. Blended learning: Research perspectives, (vol. 2), Routledge, New York, 2014

[20] P. Ramsden. A performance indicator of teaching quality in higher education: The course experience questionnaire, Studies in Higher Education, Vol.16, 129-150.

[21] P. Ramsden. Learning to teach in higher education, Routledge Falmer, London, 2003.

[22] M. Oliver, K. Trigwell. Can "blended learning" be redeemed? e-Learning, Vol.2, No.1, 17-25.

[23] M. Driscoll. Blended learning: Let's get beyond the hype, 2002. Available online from http://www07.ibm.com/services/pdf/blended_learning.pdf

[24] J. Hofmann. Why blended learning hasn't (yet) fulfilled its promises, in C. J. Bonk, C. R. Graham (Eds.), Handbook of blended learning: Global perspectives, local designs, 2740, Pfeiffer Publishing, San Francisco, CA, 2006.

[25] A. Heirdsfield, S. Walker, M. Tambyah, D. Beutel, Blackboard as an online learning environment: What do teacher education students and staff think?, Australian Journal of Teacher Education, Vol.36, No.7, 1-16.

[26] D. R. Garrison, N. D. Vaughan. Blended learning in higher education framework, principles, and guidelines, JosseyBass, San Francisco, CA, 2008.

[27] K. Sriprasertpapap. The development of online training model for Srinakharinwirot University in Thailand, Procedia - Social and Behavioral Sciences, Vol.197, 19131917.

[28] N. Tananuraksakul. Blended e-learning as a requirement for teaching EFL in a Thai academic context, Teaching English with Technology, Vol.16, No.4, 48-55.

[29] D. Thomas. Blended learning behavior of university students and academic performance in Thailand, RJES, Vol.5, No.2, 12-24.

[30] R. Woods, J. D. Baker, D. Dave. Hybrid structures: Faulty use and perception of web-based courseware as a supplement to face-to-face instruction, Journal of Internet and Higher Education, Vol.7, No.4, 281-297.

[31] N. Simasathianaophon. A perspective on blended learning approach through course management system: Thailand's case study, International Journal of Information and Education Technology, Vol.4, No.2, 172-175.

[32] H. Kanuka, C. Brooks, N. Saranchuck. Flexible learning and cost effective mass offerings, Paper presented at the Improving University Teaching (IUT) conference, Vancouver, CA, 2009.

[33] L. M. Jeffrey, A. C Kinshuk, A. Laurs, S. Mann, eLearning profiles: Diversity in learning, Massey University, Auckland, 2006.

[34] N. Zepke, L. Leach, T. Prebble. Being learner centred: One way to improve student retention?, Studies in Higher Education, Vol.31, No.5, 587-600.

[35] O. Delialioglu. Student engagement in blended learning environments with lecture-based and problem-based instructional approach, Journal of Educational Technology and Society, Vol.15, No.3, 310-322.

[36] T. H. Wang. Developing web-based assessment strategies for facilitating junior high school students to perform selfregulated learning in an e-learning environment, Computers \& Education, Vol.57, No.2, 1801-1812.

[37] R. E. Mayer, R. Moreno. Aids to computer-based multimedia learning, Learning and Instruction, Vol.12, No.1, 107-119.

[38] S. Merriam. Qualitative research: A guide to design and implementation, Jossey-Bass, San Francisco, CA, 2009.

[39] E. Olejarczuk. The e-learning component of a blended learning course, Teaching English with Technology, Vol.14, No.3, 58-68.

[40] I. E. Allen, J. Seaman, D. Lederman, S. Jaschik. Conflicted: Faculty and online education, Inside Higher Ed \& Babson Survey Research Group, Babson Park, MA, 2012.

[41] C. Anderson. Barriers and enabling factors in online teaching, International Journal of Learning, Vol.14, No.5, 241-246. 
[42] R. Becker, L. Jokivirta. Online learning in universities: Selected data from the 2006 observatory report, Observatory on Borderless Higher Education (OBHE), London, 2007.

[43] C. Heaton-Shrestha, S. May, L. Burke. Student retention in higher education: What role for virtual learning environments?, Journal of Further \& Higher Education, Vol.33, No.1, 83-92.

[44] E. J. François. Transcultural blended learning and teaching in postsecondary education, Information Science Reference, Hershey, PA, 2013.

[45] P. Pagram, J. Pagram. Issues in e-learning: A Thai case study, The Electronic Journal of Information Systems in Developing Countries, Vol.26, No.6, 1-8.

[46] R. M. Gagne, M. P. Driscoll. Essentials of learning for instruction, Prentice Hall, Upper River Saddle, NJ, 1988. 